\title{
U.S. Protectionism and Trade Imbalance between the U.S. and Northeast Asian Countries ${ }^{1}$
}

\author{
S. -C. Park
}

Sang-Chul Park - Doctor, Professor, Graduate School of Knowledge Based Technology and Energy, Korea Polytechnic University; 2121, Jeongwang-Dong, Siheung-City, Gyeonggi-Do, 429-793, Korea; E-mail: scpark@kpu.ac.kr

\begin{abstract}
Trade growth has slowed since the global financial crisis. In 2016, growth in the volume of world trade was 1.9\%, down from the 2.8\% increase registered in 2015. Imports to developed countries will be moderate in 2017, while demand for imported goods in developing Asian economies could continue to rise. Despite rising imports into Asia, the ratio of trade growth in the world has been lower than the ratio of global economic growth since 2013. Therefore, many countries have tried to create bilateral, multilateral, regional and mega free trade agreements (FTAs) in order to boost their trade volumes and economic growth. East Asian countries try to build regional FTAs and participate in different mega FTAs such as the Regional Comprehensive Economic Partnership (RCEP) and the Trans-Pacific Partnership (TPP). As a result, their economic interests are rather deeply divided and are related to political and security issues in the East Asian context. At the same time, the protectionism led by the Trump administration in the U.S. stands in contrast to the approach taken by East Asian countries. This paper deals with this development and explores why the U.S. has turned from free and open trade toward so-called fair trade based on a policy of "America first." It also offers an analysis of the reasons for trade imbalances between the U.S. and Northeast Asian countries. Finally, it evaluates how U.S. protectionism will affect mega FTAs as well as East Asian economic cooperation.

This work was supported by the National Research Foundation of the Korean government (NRF2015S1A3A2046684).
\end{abstract}

Key words: protectionism; mega FTAs; economic growth; trade imbalance; free trade; fair trade

For citation: Park S.-C. (2018) U.S. Protectionism and Trade Imbalance between the U.S. and Northeast Asian Countries. International Organisations Research Journal, vol. 13, no 2, pp. 76-100 (in Russian and English). DOI: 10.17323/1996-7845-2018-02-05.

\section{Introduction}

Global trade has contributed to rapid economic growth in the world since the second half of the 20th century. However, growth in global trade has slowed particularly since the financial crisis of 2008. The growth in the volume of world trade (goods and services) reached only 1.9\% in 2016 although its forecast was $2.8 \%$. The World Trade Organization (WTO) forecasted that the world trade volume would grow by $2.4 \%$ in 2017 , while the International Monetary Fund (IMF) projected a trade volume growth of $3.8 \%$ in the same year. The growth of global gross domestic product (GDP) may rise by $3.4 \%$ in 2017 and it rose $3.1 \%$ last year. Deep uncertainty

${ }^{1}$ The editorial board received the article in November 2017. 
about near-term economic and policy developments increase the forecasted risk in 2017. The slowdown in emerging markets was the main reason why global trade growth was lower than expected in 2016. However, emerging markets, particularly in East Asia, are expected to return to modest growth in 2017 [WTO, 2017a; IMF, 2017].

The volume of world trade in merchandise has tended to grow an average of 1.5 times higher than the world GDP growth from 1981 to 2016. During the 1990s, it grew more than twice higher. However, the ratio of trade growth to GDP growth has become more or less equal since the global financial crisis. In 2016, the trade growth rate fell lower than the output rate for the fourth time since 1981 . For this reason, many countries have tried to create bilateral, multilateral, regional and mega FTAs in order to boost their trade volumes and economic growth [WTO, 2017a] (Fig. 1).

\section{— $\%$ of World Merchandise Trade Growth to World Real GDP Growth}

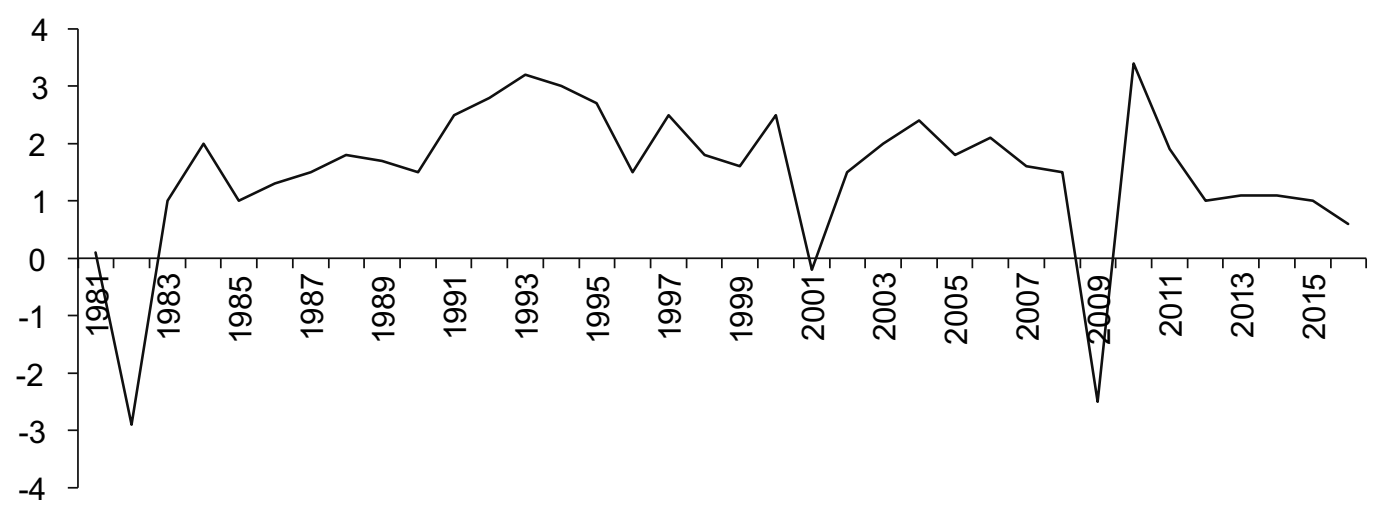

Fig. 1. Ratio of World Merchandise Trade Growth to World Real GDP Growth, 1981-2016 (as \% Change and Ratio)

Source: [World Trade Organization (WTO), 2017b].

Trade patterns have changed dramatically, particularly in last two decades. First, the intensity of economic growth has shifted from the West to the East. Increasingly, global supply chains have linked developed and developing countries, and emerging economies have accounted for a majority of global economic growth since the global financial crisis. Second, regional trade arrangements such as free trade agreements (FTAs) have proliferated on a global scale, but nowhere more so than in Asia [Hearn, Myers, 2015].

In 2016, there were 228 FTAs, and among them 147 were signed and in effect in the AsiaPacific region. There are 68 FTAs still in negotiation, five that have been signed but are not yet in effect, and three that have been discontinued. All of these agreements are either bilateral or multilateral. Singapore leads in terms of its participation in 33 FTAs and India follows with 28. Three major East Asian countries - Korea with 25, Japan with 24 and China with 23 - play significant roles in FTAs due to their national economic sizes and economic growth strategies in the region [Asia Regional Integration Center, 2017].

However, it is becoming harder to complete FTAs either because of a lack of interest on the part of government authorities or owing to the political difficulties during ratification by legislative bodies. Despite this trend, the number of FTAs is still increasing, but rather slowly compared with pace in the 1990s and 2000s. The number of new FTAs has dropped to approxi- 
mately $10 \%$ per year since the global financial crisis. At the same time, recent FTAs have tended to have broader coverage in terms of goods and services and involve more countries, resulting in the emergence of plurilateral and mega FTAs [Genereux, 2017] (Fig. 2).

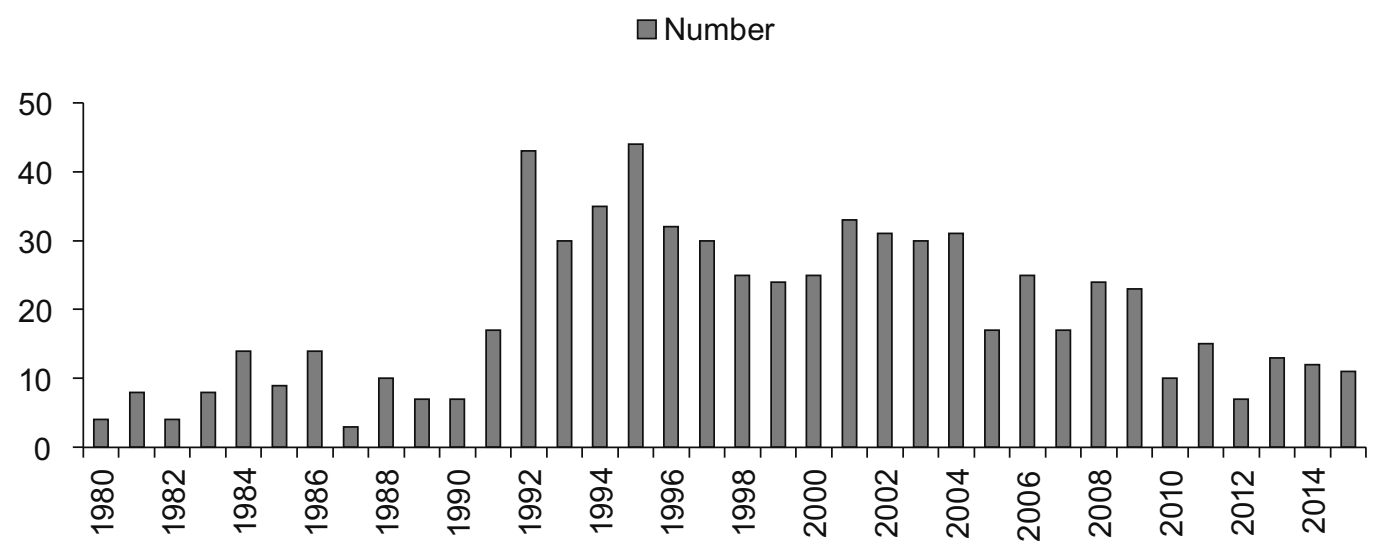

Fig. 2. Number of New Free Trade Agreements per Year (1980-2015)

Source: [Genereux, 2017].

In addition to bilateral, multilateral and plurilateral FTAs, the Asia-Pacific region has become the common ground for mega FTAs such as the Regional Comprehensive Economic Partnership (RCEP) led officially by the Association of Southeast Asian Nations (ASEAN) but practically by China, and the Trans-Pacific Partnership (TPP) led originally by the United States. China is negotiating the RCEP with 10 ASEAN members and six nations with which ASEAN has existing trade agreements. The ambition of the RCEP is to promote regional economic integration in East Asia. Among the 16 nations in the RCEP, seven nations were participating in the TPP as well. The TPP was intended to balance U.S. political and economic interests against emerging Chinese influence in the region as a part of its global strategy.

The RCEP was expected to be completed by the end of 2016, but is still in process. It was rescheduled for completion in 2017, a timeline pushed by China because it had already announced by President Xi that the free trade mechanism based on globalization would be protected at the World Economic Forum in 2017. However, the RCEP negotiations at the November 2017 Asia-Pacific Economic Cooperation (APEC) summit were not successful and the deal has been delayed to 2018. The TPP faced turbulence after the Trump administration announced its withdrawal from the proposed agreement in January 2017 despite the fact that 12 states had already committed to the TPP in October 2016. As a result, the future of mega FTAs in the Asia Pacific region has become unforeseeable particularly in the TPP. However, the remaining TPP members signed on to a revised version of the agreement, the Comprehensive and Progressive Agreement for Trans Pacific Partnership (CPTPP), in March 2018 [Graceffo, 2017; Nhan Dan, 2017; Mathieson, 2017; Financial Times, 2018].

Since the Trump administration took office in January 2017, U.S. protectionism in terms of trade has become apparent in a new focus on creating jobs and attracting foreign direct investment (FDI) in the domestic market based on high tariffs for imported goods and tax reductions on exported goods. U.S. protectionism is based on mercantilist principles which regard world trade as a game with winners and losers measured in terms of their trade balances. Therefore, the U.S. government is critical of China, Japan and Korea, and all free trade agreements 
such as the North American Free Trade Agreement (NAFTA) and the Korea-United States (KORUS) FTA. Based on mercantilisms' simplistic analytical framework, President Trump ordered withdrawal from the TPP and is seeking to renegotiate NAFTA and the KORUS. In line with his policy, the U.S. government has considered punitive tariffs against China, while pressuring domestic firms to alter their economic decisions to invest abroad. In doing so, the U.S. government has strongly signaled that it may reevaluate America's role in the global economic and geopolitical order [Genereux, 2017; Feinman, 2016; USTR, 2017a; USTR, 2017b].

This paper deals with U.S. protectionism in the Trump administration and explores the shift from free and open trade toward so-called fair trade based on a protectionist policy of "America first." It also focuses on trade imbalances between the U.S. and Northeast Asian countries and analyzes how such imbalances have developed. Finally, it considers how U.S. protectionism under the Trump administration will affect mega FTAs in the Asia Pacific region as well as East Asian economic cooperation. The paper draws on various research methods including a critical analysis of literature, an inference method and statistical analysis.

\section{Theoretical Debates}

Most mainstream economists would agree with the recent rebuttals to the skepticism about the liberal trading order. However, because intellectual and political support for free trade in the U.S. and elsewhere has weakened, protectionism has reemerged as a plausible option in many countries, and particularly in the U.S. under the Trump administration.

Mainstream economic theory suggests that comparative advantages and economies of scale create economic gains through economic efficiency. Tariffs lead to competitive tariff retaliation, which results in a massive shrinkage in foreign trade and decreased global economic growth. Economic theory never claimed that free trade is good for all industries and all people. However, the winners from free trade can afford to compensate the losers. As a result, everyone could be made better off because the aggregate gains are positive [O'Rourke, Williamson, 2001; Rosen, 2008].

Economic theory also says that resources will flow to more efficient uses. However, this does not apply when governments and markets do not work well. In contrast, many East Asian countries soared after a shift to market economics although it can be argued that they profited not from the free trade, but from the export-led growth and high levels of protectionism. Compared to East Asian countries, sub-Saharan Africa has generated only low levels of economic growth because its exports are mostly primary products, natural resources, intermediate goods and people. Moreover, bitterness in Latin America about neoliberalism's focus on free trade and globalization caused a shift to the political left and more state intervention. As a result, there is a perception in South America that global free trade based on globalization is unfair and creates poverty instead of wealth [Lawrence, Weinstein, 1999; Ocampo, 2004].

Even in China there is a strong policy reorientation, particularly since the global financial crisis, moving away from further global liberalization and toward bilateral and politically oriented FTA's in Asia aimed at reducing U.S. influence in the region. Since the global financial crisis, support for globalization world-wide has clearly declined, and dramatically so in the U.S. [Hillebrand, Lewer, Zagardo, 2010; Chicago Council on Global Affairs, 2010a, 2010b].

Samuelson argued in 1972 that aggregate gains from trade are not necessarily positive for all economies. He expanded his idea further to claim that economic growth in the rest of the world can damage a country if it takes place in sectors that compete with its own comparatively disadvantaged export sectors. As a result, a state's relative and even absolute GDP per capita can fall. Gomory and Baumol extended Samuelson's theory and urged that there are several 
possible equilibria with vastly different outcomes for states in a free trading global economy. They note that it is perfectly possible and even common for a state's equilibrium trade outcome to be less than that required for self-sufficiency; thus, good equilibria are often created rather than bestowed by nature. Accordingly, states can do much to affect their trading outcomes, and as a result they urged the U.S. to adopt protectionist measures [Samuelson, 2004; Gomory, Baumol, 2009].

However, Bhagwati argues that Samuelson's explanation cannot be used as a justification for U.S. protectionism. He also denies Gomory and Baumol's argument because, even while true, the U.S. could not carry out effective industrial policies to remedy its trade outcome. Krugman and Obsfeld support Bhagwati's view that it is an empirical question rather than a fact whether the growth of East Asian countries has actually hurt advanced countries, even while a theoretical possibility still exists [Bhagwati, 2009; Krugman, Obsfeld, 2009].

Economists have developed theoretical models for free trade and estimated welfare gains from reducing or eliminating trade barriers. In line with these models, Krugman and Broda and Weinstein suggested that free trade benefits society through gains in overall quality and variety. However, this standard static growth from free trade has left trade promoters quite vulnerable because the static growth models consider only short-run partial equilibrium efficiency gains. At the same time, the static models generate gains from a trade range between $0.5 \%$ and $2 \%$ of GDP, which is not impressive [Krugman, 1997; Broda, Weinstein, 2006].

In order to deepen the findings of theoretical models regarding long-term efficiency gains and the contribution of free trade to economic growth, economists have developed dynamic models by estimating the impacts of trade liberalization used by cross-country regressions. Using these models, Bradford, Greico and Hufbauer argued that the U.S. economy in 2005 could have been between $\$ 800$ billion and $\$ 1.4$ trillion larger without post-war trade liberalization. However, Acemoglu left the issue of trade and growth undecided; because various models highlight both positive and negative effects of trade on economic growth, further empirical work must be conducted. Accordingly, Lewer and Van den Berg pointed out that further development of dynamic models and additional empirical research are required. Additionally, linkages between trade and technology as well as trade and institutional quality must be further developed [Bradford, Greico, Hufbauer, 2006; Acemoglu, 2009; Lewer, Van den Berg, 2007; Feenstra et al., 2009].

This paper adopts dynamic models despite the necessity of further development rather than the static models because the former can explain the long-term benefits of free trade more precisely than the latter. Accordingly, the conservative dualism of trade theory explains why U.S. protectionism has emerged since the global financial crisis and it captures the trade policy of the Trump administration better than any other theoretical background. However, it has limitations regarding its contribution to sustainable global economic growth. The dynamic models based on long-term efficiency gains and economic growth can correct the direction of protectionism toward free trade. Furthermore, it also provides an explanation of why the trade imbalance between the U.S. and East Asian countries has taken place in general and widened in 21st century in particular [Dunn, 2015].

\section{Globalization and U.S. Protectionism}

\section{Background}

World trade has played a significant role in global economic growth and globalization since World War II. However, it has slowed substantially, particularly since the global financial crisis in 2008. It grew an average of $16 \%$ per year from 2003 to 2008 - this is a fairly high growth 
rate. However, world trade in merchandise dropped to $1.5 \%$ per year from 2010 to 2015 , while world trade in services declined from $15 \%$ to $4.4 \%$ during the same period [WTO, 2016].

Several years of relatively high economic growth prior to the global financial crisis and large income inequality after the crisis contributed to the emergence of political populism in the EU and the U.S., resulting in the Brexit referendum in the UK and the Trump administration in the United States. Paradoxically, pro-globalization leaders such as the U.S. and the UK turned to a deglobalization process based on protectionism. As a result, the world is witnessing a combination of economic and political risks at present that could severely affect the global economy. Many states, particularly in East Asia, have begun to fear the deglobalization movement and accompanying protectionist sentiment because these policy shifts could have negative impacts on their national economic growth strategies.

The globalization trend can be measured by observing key economic indicators such as trade volume and flows and FDI. Furthermore, the application of tariff and nontariff barriers on trade is also a useful tool to measure the trend. On the contrary, restrictions imposed by governments on labour movements and national policies to encourage the purchase of local products are regarded as reflections of the deglobalization trend [Basu Das, 2017].

\section{The Globalization Trend in the World Economy}

Globalization of the world economy has contributed to increasing integration of world's labour, product and capital markets within a rules-based system represented by high world trade growth and global FDI flows over the past five decades. The globalization trend is not new; the first wave of globalization occurred from the mid-19th to the early-20th century. During this period, the impact of globalization was visible on many levels. International trade increased sharply at the same time as the share of GDP for trade in many countries also grew. The rapid growth of world trade was related to declining transportation costs and tariffs which eliminated cross-border price differences on many basic commodities. As a result, markets became truly global. Additionally, labour mobility surged from the labour-abundant and resource-poor European periphery - Ireland, Italy, Austria-Hungary, Russia and Scandinavia - to the labourscarce and resource-abundant new world - the U.S., Canada, Australia, Argentina and Brazil [Maddison, 2001; Feinman, 2016].

Moreover, capital flows also increased from wealthy European countries such as the UK, France and Germany to the new world that generated large current account surpluses and channeled nearly half of domestic savings abroad. These capital flows were mostly in the form of portfolio investments to finance infrastructure projects such as canals, railroads and mines in the new world which reinforced migration. Based on such strong capital investment across the Atlantic, capital markets became more global. As a result, the price difference between comparable bonds traded in London and New York largely disappeared particularly after the first trans-Atlantic cable in 1866 [Garbade, Silber, 1978] (Fig. 3).

These powerful globalization forces united many parts of the global economy between the Atlantic and Oceania. Free trade, capital flows and international migration provided countries with the benefits of specialization and distributed resources where they were most needed and where they would earn the highest returns. In fact, globalization allowed all countries that were able to take part in the international system to benefit freely. At the same time, it also contributed to income convergence across countries which allowed poor countries to grow quickly. However, globalization also created negative impacts that widened income inequality within wealthier countries and caused real income to fall in poor countries in the Atlantic areas [O’Rourke, Williamson, 2001]. 
Net Migration (1870-1913) (per 1,000 people)

$\nabla$ Real Wages (1870) (index $=100$ in UK in 1905)

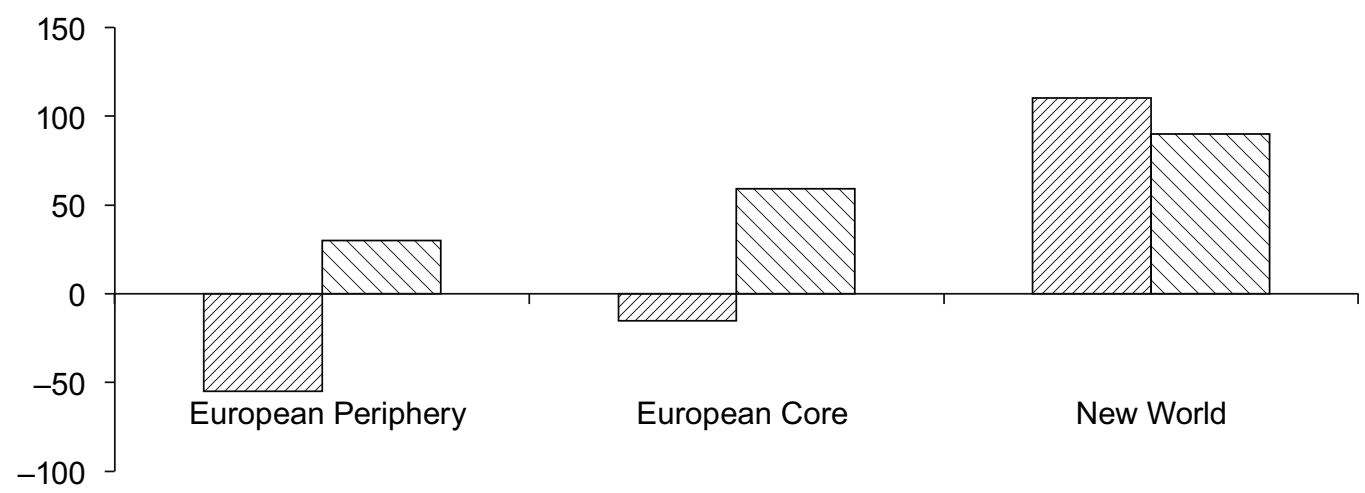

Fig. 3. Net Migration and Real Wages between Europe and the New World (1870-1913)

Note. European periphery refers to Ireland, Italy, Portugal, Spain and Scandinavia; European core refers to the UK, France, Germany, Netherlands and Belgium; New world refers to the U.S., Canada, Australia, Argentina and Brazil.

Source: [O’Rourke, Williamson, 2001].

Due to these distributional effects, a strong political backlash against globalization took place. As a result, political pressure increased to roll back globalization, although the integrated world based on technologies was not abolished. The U.S., particularly the industrialized north, started to raise tariffs in order to increase revenues during the Civil War and kept them high for decades. Even in the UK, high tariffs were imposed in the early-20th century when the UK's industrial bases started to be challenged from abroad. The main impetus for the political backlash was pressure from a working class that had begun to gain political power. The native working class was threatened by the influx of immigrants, which resulted in the anti-globalization movement. Ultimately, the first era of globalization collapsed with World War I in 1914 and the Great Depression in 1929 after which countries raised tariffs to autarkic levels, imposed rigid control on capital flows and restricted immigration [Higham, 1955; Feinman, 2016].

The U.S. tried to restore an open and integrated global economic order by creating supranational organizations such as IMF, the World Bank and the General Agreement on Tariff and Trade (GATT) after World War II. These organizations aimed at coordinating policies, supporting economic growth and supervising the transition away from protectionism, while the U.S. dollar became the key currency in a fixed exchange rate system based on the gold standard and later in a floating exchange rate system. Tariff and nontariff barriers were reduced, immigration restrictions were eased and capital controls were lifted. The end of the Cold War gave a major boost to this second wave of globalization as many formerly closed economies such as China, India and Eastern Europe liberalized their economies and joined the global economic system by adopting standards established by the WTO [Feinman, 2016].

Since the establishment of the WTO in 1995, the global trade of goods increased significantly. The total volume of global trade of goods accounted for $\$ 5$ trillion in 1995 and increased almost fourfold to $\$ 18.5$ trillion in 2014 . At the same time, global trade contributed 
substantially to economic growth. Global trade and global GDP are closely correlated. As global trade grows, a higher global GDP is generated. Periodically, global trade increased by an average of $7 \%$ while the global GDP grew an average of $3.4 \%$ between 1995 and 2000 . These changed $5 \%$ and $2.9 \%$ respectively between 2000 and 2005, and $3.5 \%$ and $2.3 \%$ between 2005 and 2010. It declined further and they both made parity in 2014 with $2.5 \%$ growth [WTO, 2015, 2016] (Fig. 4).

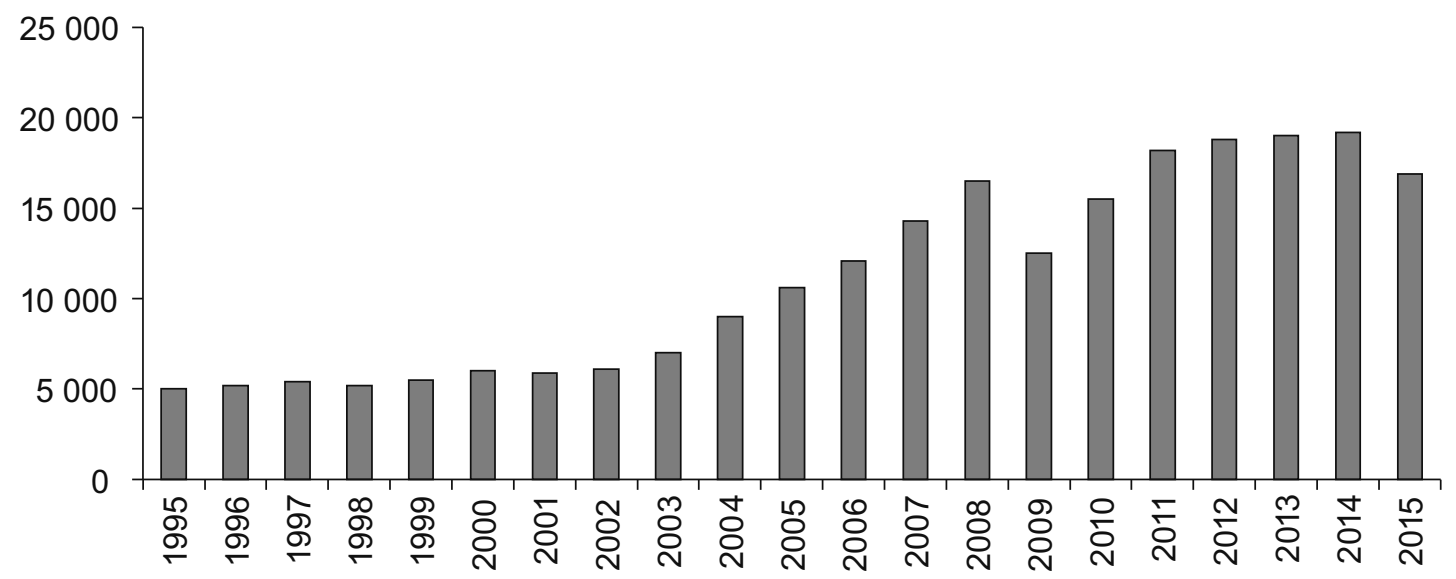

Fig. 4. Global Trade of Goods (1995-2015)

Source: [WTO, 2016].

Capital investment shows the same trend as global trade in the same period. Global FDI net inflows increased from around $\$ 320$ billion in 1995 to $\$ 3.1$ trillion in 2007. They declined from this peak to $\$ 1.8$ trillion in 2014 and increased to $\$ 2.2$ trillion in 2015 - this represents a nearly sevenfold expansion from 1995 to 2015. The share of global FDI in global GDP accounted for $1.1 \%$ in 1995 and increased to $5.2 \%$ in 2007. The global FDI net inflows reached a peak in that year and then declined to $2.2 \%$ in 2009 due to the global financial crisis. They increased slightly to $2.2 \%$ in 2014 and to $2.8 \%$ in 2015 . Capital investment and global trade are correlated as well. When capital investment increased sharply in 2000 and 2007, global trade also started to increase rapidly after 2003. There was a downturn in 2009 due to the strong impact of the global financial crisis on the global economy [World Bank, 2017] (Fig. 5).

Increasing global trade and FDI net inflows have made possible the significant reduction of tariff rates, particularly since the new global trade system enforced by the WTO began in 1995. Since then, the weighted mean for tariff rates in all products declined from $33.96 \%$ in 1996 to $2.88 \%$ in 2012. Of note is the significant one-year decline in tariff rates from $33.96 \%$ in 1996 to $5.34 \%$ in 1997, no doubt a result of the WTO's impact. Since then, the tariff rate has reduced continuously but more moderately [World Bank, 2017] (Fig. 6).

Although tariffs have been reduced continuously, nontariff barriers have remained. Political leaders worldwide became concerned about the global trading system after the global financial crisis that caused both developed and developing economies to experience a simultaneous downturn. The number of unemployed people in the world increased from 14 million to 
38 million in 2009 and caused income inequality and political instability in many nations. In these circumstances, strong protectionist sentiments emerged. G20 leaders agreed to fight against protectionism in the 2008 Washington summit but paradoxically, large G20 economies such as the U.S., Russia, India, Brazil, Japan and the UK were applying the most trade-restrictive measures by 2015 - the number of discriminatory measures applied in 2015 increased 50\% from 2014. This trend indicates that protectionism has emerged recently rather strongly [Park, 2016; Basu Das, 2017] (Fig. 7 and Table 1).

— Share of Global GDP

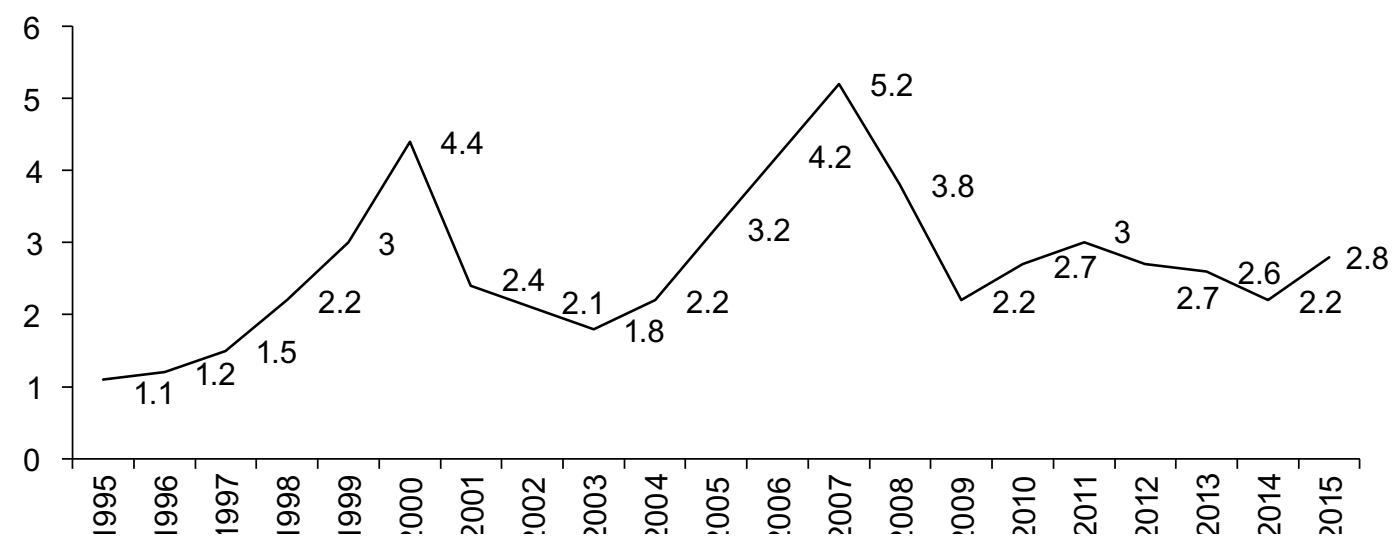

Fig. 5. Trend of Global FDI Net Inflows (1995-2015)

Source: [World Bank, 2017].

— Tariff Rate

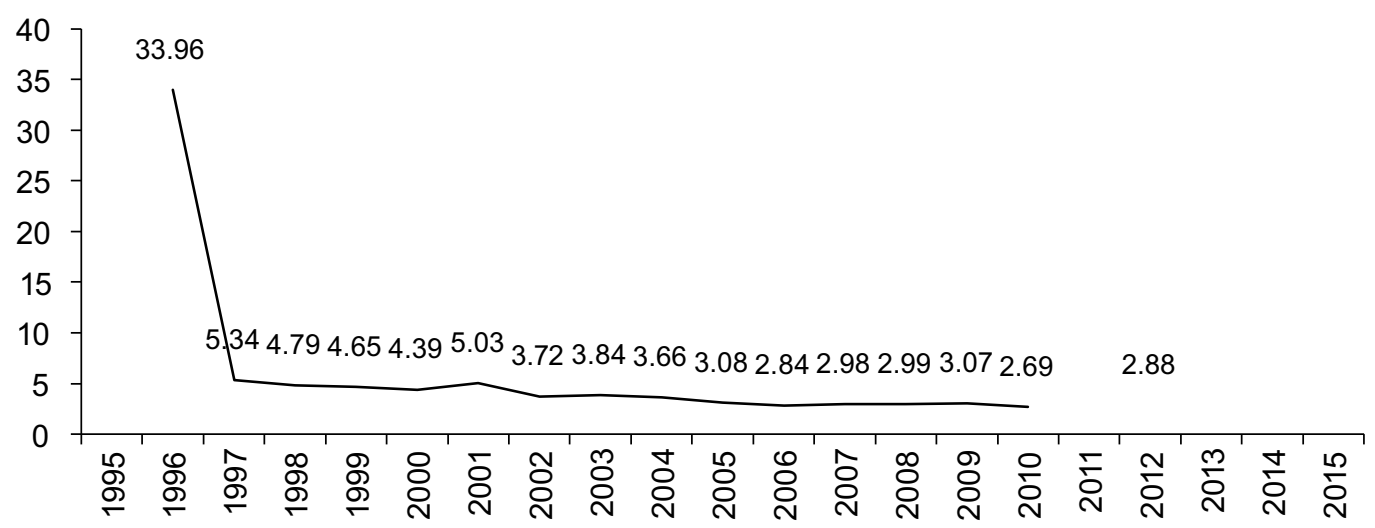

Fig. 6. Trend of Tariff Rates (1995-2015, \%)

Source: [World Bank, 2017]. 


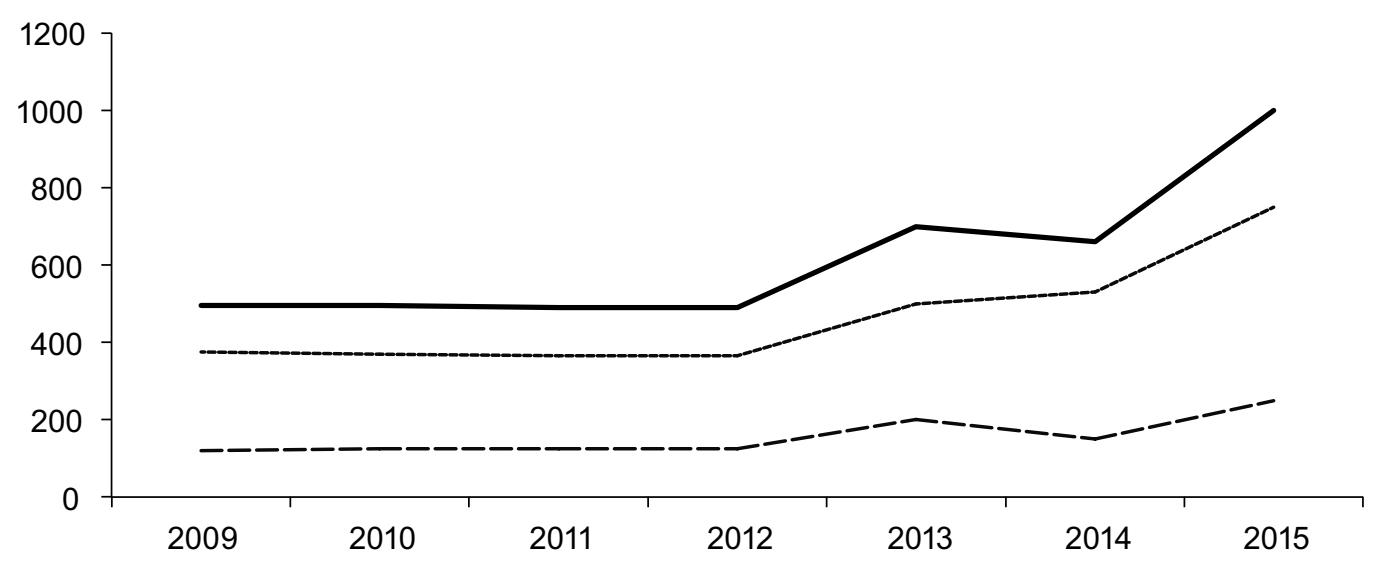

Fig. 7. Number of Implemented Measures in the World

Source: [Global Trade Alert, 2016].

Table 1. Major Countries Imposing Discriminatory Measures in 2015

\begin{tabular}{|c|l|c|c|}
\hline Rank & Countries & $\begin{array}{c}\text { No. of Measures Imposed } \\
\text { in 2015 }\end{array}$ & $\begin{array}{c}\text { Share of World Imports } \\
\text { in 2014 }\end{array}$ \\
\hline 1 & U.S. & 90 & 13.5 \\
\hline 2 & Russia & 86 & 1.6 \\
\hline 3 & India & 67 & 2.6 \\
\hline 4 & Brazil & 42 & 1.3 \\
\hline 5 & Indonesia & 42 & 1.0 \\
\hline 6 & Argentina & 36 & 0.4 \\
\hline 7 & Japan & 36 & 4.5 \\
\hline 8 & UK & 36 & 3.8 \\
\hline 9 & Italy & 34 & 2.6 \\
\hline 10 & Canada & 27 & 2.6 \\
\hline
\end{tabular}

Source: [Global Trade Alert, 2016].

\section{U.S. Protectionism}

Protectionist sentiments reemerged in 2015 led by the U.S. - the largest economy in the world - and have severely affected global economies. Protectionist trade policy has always existed, even in the global free trade system. Although tariffs on trade in advanced and developing countries have declined continuously since the 1980s, nontariff barriers started to increase in the 1990s. U.S. protectionism is regarded as in line with this trend. U.S. protectionism has a significant impact on the global economy due to its economic size compared with other economies. Therefore, it is wise to investigate three major reasons for the increase in U.S. protectionism. 
The first reason for increasing U.S. protectionism may be that income and distribution inequality in the U.S. has risen since the 2000s. Economists are not sure yet whether free trade has created this income inequality. Some economists argue that free trade caused only about $20 \%$ of the increase in inequality in the 1970s and 1980s when U.S. trade was mostly North-North. However, the shift of trade relations to a North-South pattern in the 1990s has caused a negative impact on the wages of low-skill workers in the United States. Whatever the cause of this rise in inequality, the fact is that the average of the real wage of production per hour has been stagnant since the 1980s. As a result, the wage increase in production has lagged behind growth in real GDP per capita. Moreover, the share of pretax income in the top $1 \%$ increased from $10.5 \%$ in 1980 to over $20 \%$ in 2015 , while its share of bottom $50 \%$ declined from $20.5 \%$ to $13 \%$ during the same period. The U.S. is the most unequal nation among the advanced countries based on a Gini index that increased to 0.38 in 2014 [Krugman, 2008; ERP, 2009; Hillebrand, Lewer, Zagardo, 2010; OECD, 2014; Piketty, 2014; Alvaredo et al., 2017] (Fig. 8).

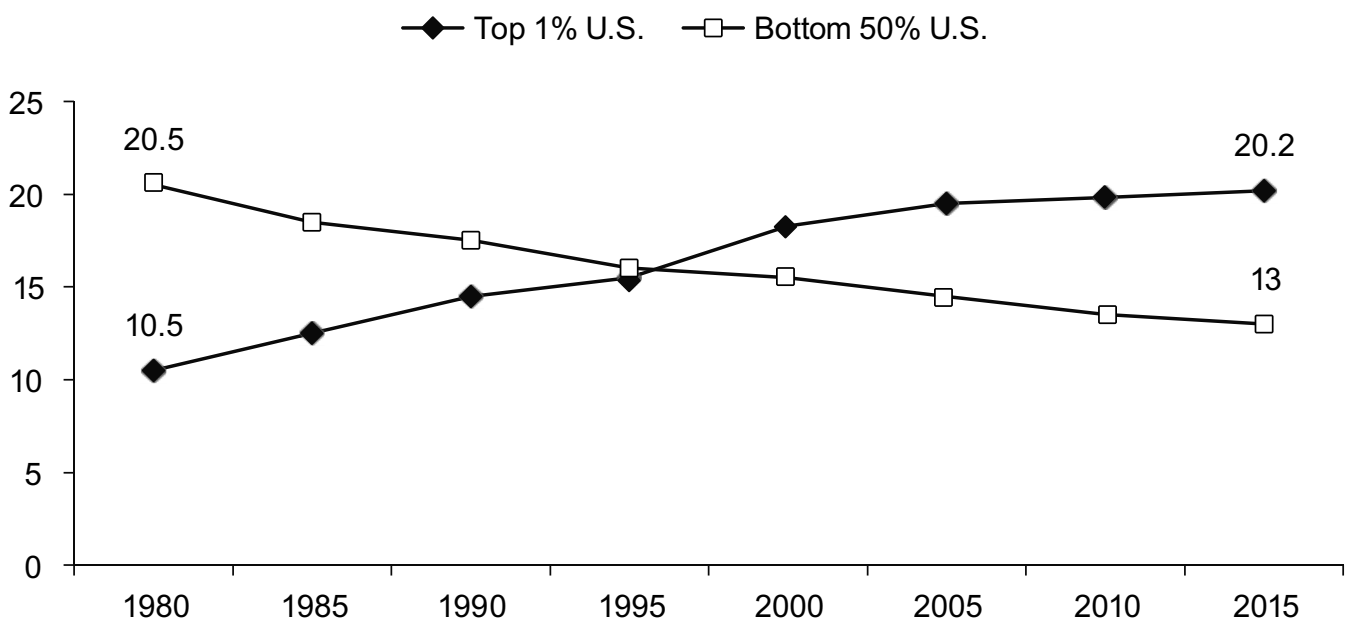

Fig. 8. Share of Pretax Income in the U.S. (1980-2015)

Source: [Alvaredo et al., 2017].

The second reason may be the rise of East Asia and its changed trade relationships with the United States. The East Asian economy has grown since World War II even without the Marshall Plan that had redeveloped Western Europe. It has been mostly developed by trade expansion based on comparative competitiveness. Certainly the U.S. market has also played a significant role for the rapid development of the East Asian economy. Japan's economy developed first during the 1960s and 1970s. The four Asian tigers - Hong Kong, Singapore, South Korea and Taiwan - followed during the 1980s and 1990s, while China emerged as an economic power in the 2000s.

The U.S. government regarded Chinese membership in the WTO as potentially promoting harmonious interdependence in the global trade system. In reality, however, the U.S. views China as a strategic rival and there has been a rising sense of vulnerability since China became the second-largest economy in the world in 2010. The U.S. government and public have a strong impression that China carries out unfair trade policies, and therefore they regard Japan and Korea as more favourable trading partners in East Asia. In addition, the U.S. government views China not only as an economic threat, but also as a multifaceted threat to the United 
States. Chinese mercantilism and its comparative advantage weakened the U.S. manufacturing sectors and industrial bases and could disturb the domestic production of weaponry in time of war because U.S. defense firms rely on many products imported from China [CCGA, 2010b; Hillebrand, 2010].

Therefore, several trade restriction measures were implemented even by the Obama government that were tariff based, but frequently regulatory. For example, the Obama government included a "buy American" clause in its economic stimulus programme in 2009. This was a protectionist policy designed to act as a domestic economic stimulus. This trend has persisted, and it has been strengthened by the Trump government in the name of "America first" [Genereux, 2017].

The third reason may be the decreased dependency of the U.S. economy on global trade. The U.S. is the second-least trade-dependent economy after Brazil. Its trade share based on GDP in 2015 accounted only for 28\%, while the Chinese share of GDP was 40\%. Countries depending on exports as a primary source of growth could be directly and negatively impacted by import tariffs and other trade restrictions. In a protectionist system, small and open economies like Korea and Thailand in East Asia or the Netherlands in Europe may be more vulnerable than large, closed economies like Brazil and the United States. This means that the U.S. economy may be the least affected, along with Brazil, in a protectionist environment [Hofschire et al., 2017] (Fig. 9).

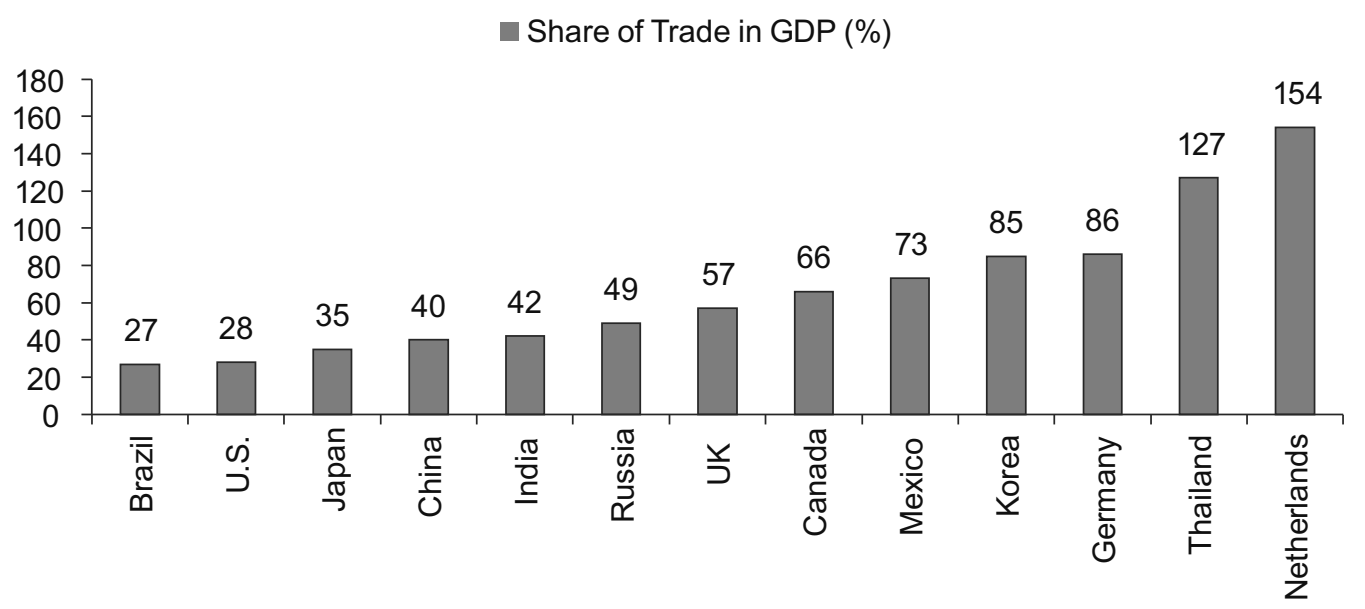

Fig. 9. Trade Openness by Country (as of 2015)

Source: [World Bank, 2017].

\section{Trade Imbalance between the U.S. and Northeast Asian Countries \\ Background}

The U.S. has had the largest trade deficit in the world over three decades since the 1970s. In the mid-1970s, the U.S. briefly held a trade surplus but has experienced continuous deficits since then. In 2005, the peak U.S. trade deficit accounted for over 5\% of the national GDP. Since then it has improved, and it fell to slightly lower than $3 \%$ of the national GDP in 2015 [Genereux, 2017] (Fig. 10). 
- As $\%$ of GDP

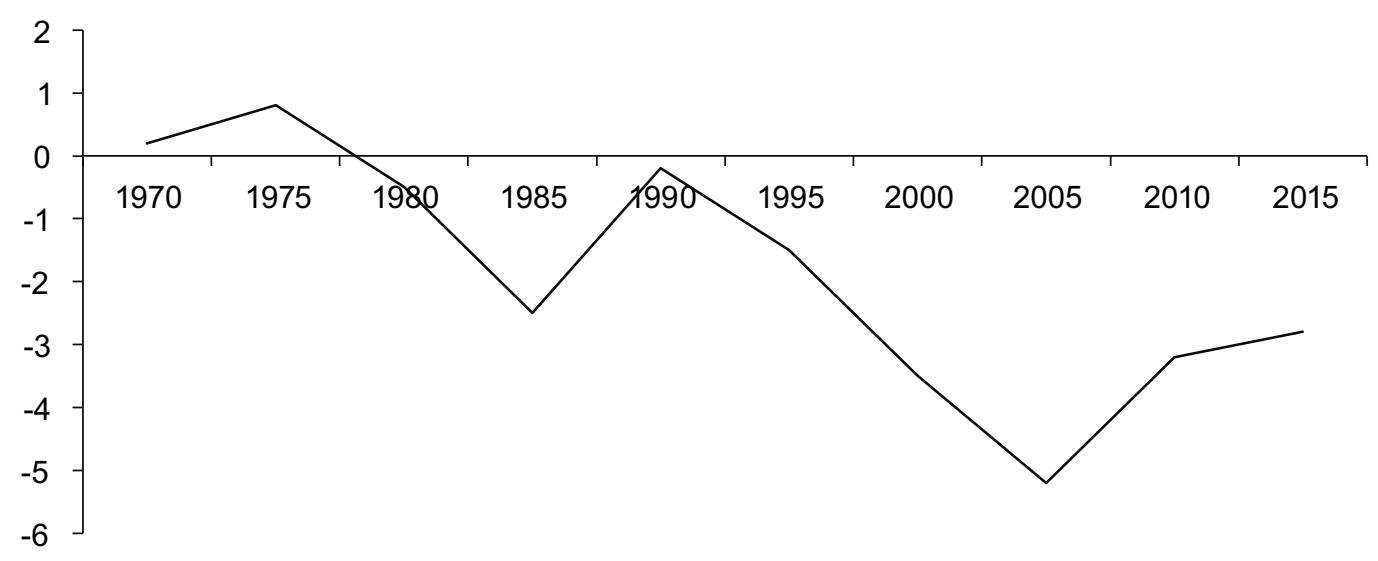

Fig. 10. The U.S. Trade Balance in Goods and Services (1970-2015)

Source: [Genereux, 2017].

Due to the increase of the U.S.'s aggregate trade deficit, President Trump criticized major U.S. trade partners such as China, Japan, Korea, Germany, Mexico and Canada during his election campaign, arguing that they have unfair trade policies which allow them to generate surpluses in their trade with the United States. In particular, the trade imbalances between the U.S. and Northeast Asian countries is a matter of concern for the United States.

\section{U.S. Trade Imbalance with Northeast Asian Countries}

The U.S.'s trade deficit with China, Japan and Korea accounted for $62 \%$ of the total trade deficit in 2015. It increased up to $72 \%$ of the total trade deficit if the trade deficit with India, Malaysia and Vietnam is included in the same year. In fact, the U.S. trade imbalance with East Asia is a chronic structural issue for both parties. The U.S. trade deficit with China, Japan and Korea in particular has become a major issue for the Trump government. The U.S. trade deficit with China accounted for $49 \%$ of the total trade deficit in 2015, a figure that overwhelms that of other nations. Therefore, President Trump announced several times during his election campaign that he would impose a $45 \%$ tariff on Chinese export goods although it was hoped that this would not take place due to severe trade friction between the two countries. Unfortunately, a trade war was started in March 2018 when the U.S. government imposed punitive tariffs on $\$ 60$ billion in Chinese imports and the Chinese government announced retaliatory measures. [Liu, Yi, Liang, 2016; Bradsher, Perlez, 2018] (Fig. 11).

The U.S. trade deficit with Northeast Asian countries has been caused by an imbalance between exports and imports. The U.S. imports much more from Northeast Asian countries than it exports to them. China was the largest country to export to the U.S., and its volume accounted for slightly more than $\$ 483$ billion in 2015 . Japan was the fourth largest exporter to the U.S. with about $\$ 131$ billion, while Korea was the sixth largest exporter with about $\$ 72$ billion in the same year. By contrast, these nations imported from the U.S. $\$ 116$ billion, $\$ 62$ billion, and $\$ 43$ billion respectively in the same year. As a result, the U.S. made up $62 \%$ of the total trade deficit with these nations in 2015 [United States Census, 2017]. 


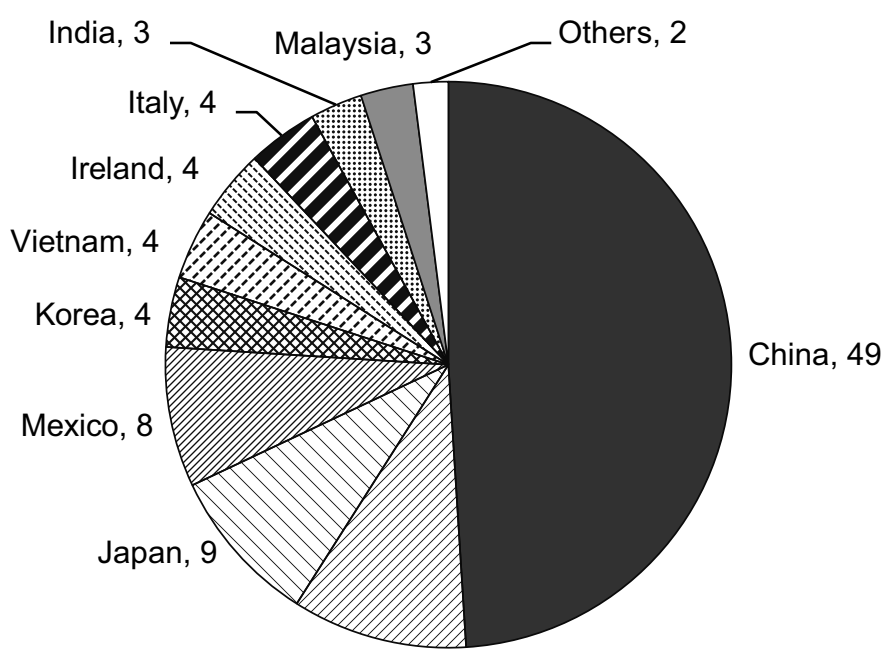

Germany, 10

Fig. 11. Composition of U.S. Trade Deficit (2015, \%)

Source: [UN Comtrade, 2016].

The U.S. trade imbalance with Northeast Asian countries is a structural phenomenon based on comparative competitiveness in trade. From 2000-2015, the Chinese trade surplus with the U.S. has increased rapidly. It rose from $\$ 83.8$ billion in 2000 to $\$ 367.2$ billion in 2015 , a more than fourfold increase, while the Japanese trade surplus increased until the mid-2000s before starting to decline from $\$ 81.6$ billion in 2000 to $\$ 69$ billion in 2015 . The Korean trade surplus shows a pattern similar to that of China's, but much more moderate. It increased from $\$ 12.5$ billion in 2000 to $\$ 28.3$ billion in 2015 , more than doubling. On the whole, Japan's position as the state with the largest trade surplus with the U.S. has been taken over by China since 2000. Additionally, the Korean trade surplus has increased continuously so that in total the U.S. trade deficit has widened during the period. The share of the U.S. trade deficit with these three nations accounted for 47.8\% in 2000 and 62\% in 2015 [United States Census, 2017] (Fig. 12).

The Trump government's economic policies are composed of three pillars: tax cuts, infrastructure investment and trade protectionism. The tax cut policy and infrastructure investment have a high probability of implementation while trade protectionism may be difficult to fully implement because of its strong impact on the global economy and the possibility of a trade war on a global scale. If the U.S. cuts taxes and increases infrastructure investment, its current account will increase because its tax revenues will decline, and infrastructure investment must be financed by U.S. government bonds. Moreover, its imports will increase rather than decrease. As a result, exports of Northeast Asian countries will increase further because the region is the global manufacturing hub. Although U.S. imports from China, Japan and Korea may decline due to U.S. protectionism, these nations are core manufacturing nations exporting to other countries from which the U.S. imports goods for its infrastructure investment. Accordingly, the increasing U.S. demand for world's manufactured goods may still eventually benefit Chinese, Japanese and Korean exports [Liu, Yi, Liang, 2016; Genereux, 2017]. 


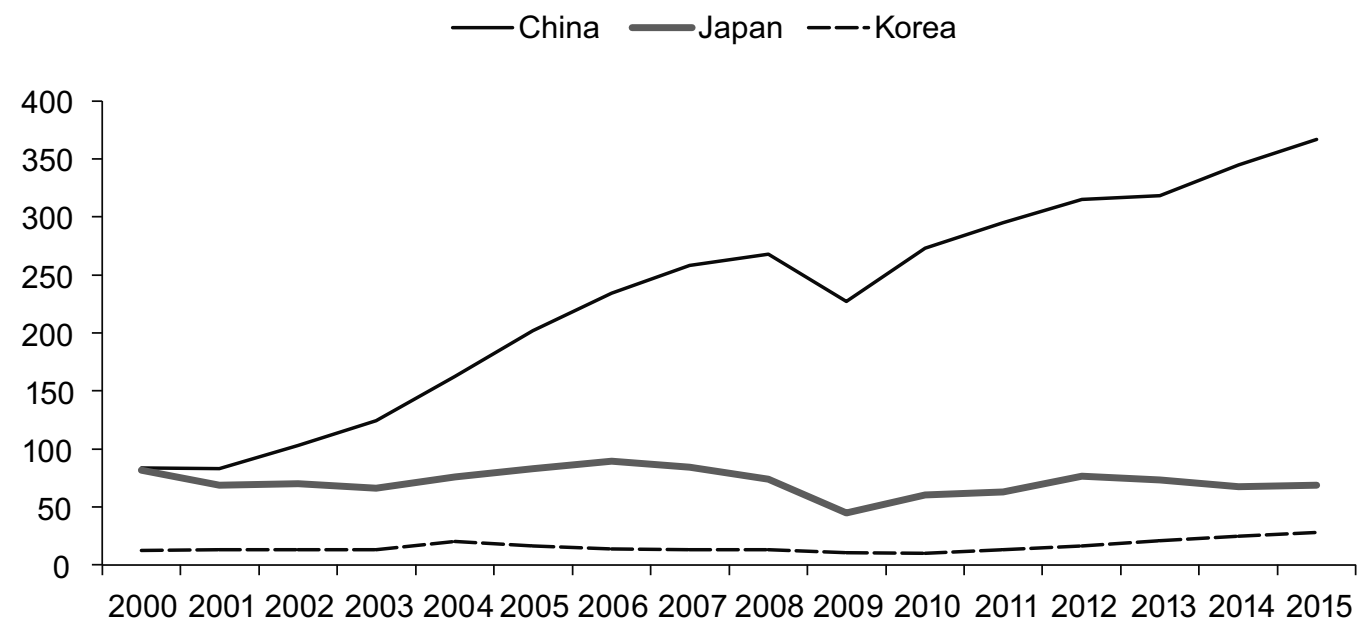

Fig. 12. The U.S. Trade Imbalance with China, Japan and Korea (2000-2015, \$ Billions)

Source: [United States Census, 2017].

\section{U.S. Protectionism and Implications for Northeast Asian Countries}

U.S. protectionism has a long history going back to the 1920s and has intensified particularly since the global financial crisis in 2008. From Obama's "buy American" clause, the Trump government has started its "America first" policy based on tax cuts, infrastructure investment and trade protectionism. In fact, U.S. protectionism is the result of a disconnect between the U.S.'s rising trade exposure and a failure to adopt the proper social expenditure policies. In other advanced economies such as Germany, Sweden and the Netherlands (but excluding the UK), both have been harmonized and accompanied by open markets [Hendrix, 2016].

Despite the domestic policy failure in social expenditure and industrial competitiveness, U.S. trade policy based on nontariff impediments has been strengthened since 2009. Given the recent data from the Global Trade Alert (GTA), the U.S. is the most protectionist country in the G20 because it implements the highest number of nontariff barriers. U.S. protectionism started under the Obama administration and continues under the Trump administration. Recent empirical analysis indicates that the increase of tariffs and nontariff barriers in advanced countries results in decisive welfare losses. Therefore, U.S. protectionist measures may have severe economic consequences [Evenett, Fritz, 2017; Aichele, Felbermayr, Heiland, 2016; Felbermayr, Steininger, Yalcin, 2017] (Fig. 13).

U.S. protectionist measures based on high tariffs for import goods and restrictions would tend to increase the value of currency and reverse the effects on import prices. Moreover, this can increase export prices in foreign markets and put the trade balance more or less at the same level as before. As a result, the decline of industrial competitiveness becomes evident over the longer term and affects economic potential more than short-term real GDP growth.

If protectionism in the Trump administration starts with high tariffs for China and Mexico - announced as $45 \%$ and $35 \%$ respectively during the election campaign - trading partners would claim compensation through the WTO or would retaliate against U.S. exports, intellectual properties and investments. It is possible to estimate how the impacts of the Trump administration's proposed trade policies on the U.S. economy based on Moody's analytics, 
specially designed to assess short-term economic shocks. It is calculated by changes in GDP, employment, private consumption and other magnitudes at a sectoral, state and county level [Noland, Robinson, Moran, 2016; Hufbauer, Jung, 2016].

$\square$ Number of Discriminatory Measures Enforced by the U.S.

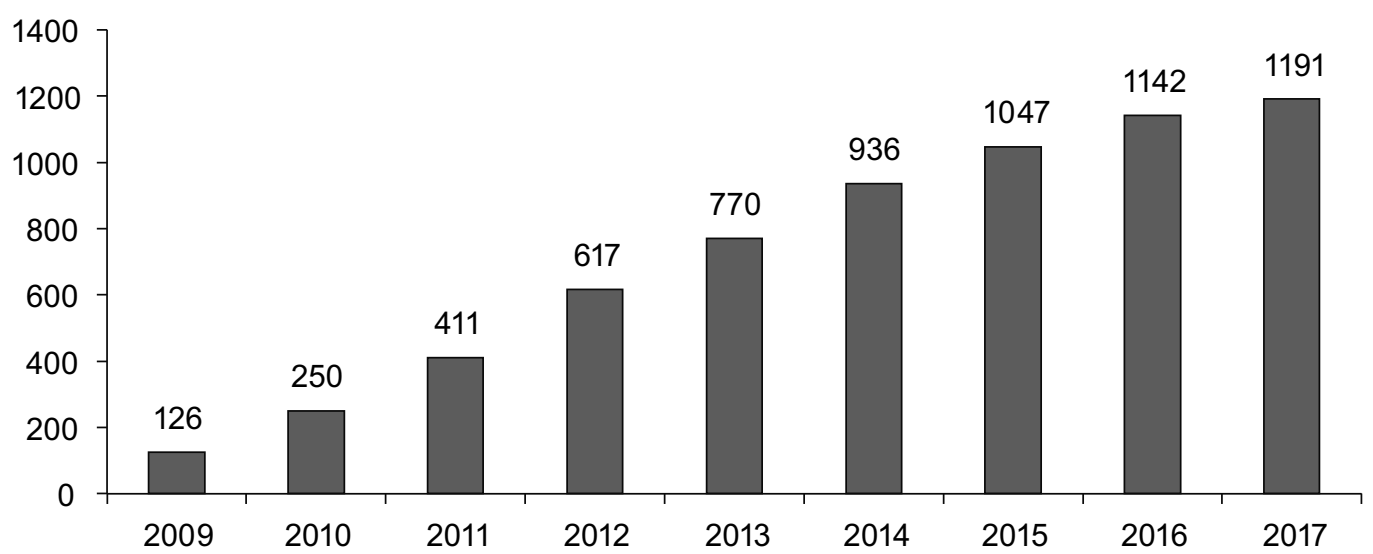

Fig. 13. Number of U.S. Discriminatory Measures Since 2009

Source: [Global Trade Alert, 2017].

This analysis is based on three scenarios such as a full trade war, an asymmetric trade war and an aborted trade war. In the first scenario, trading partners respond reciprocally to the Trump administration's new tariffs with equivalent tariffs on U.S. products. In the second scenario, China retaliates against specific U.S. exports of goods and services, while Mexico imposes its most favourable nation (MFN) tariffs on all U.S. exports. The last scenario is that U.S. tariffs are unilaterally imposed for only a single year and trading partners retaliate for the same period [Noland, Robinson, Moran, 2016].

In the full trade war scenario, the U.S.'s GDP growth is more or less flat from 2017 to 2019 and starts to increase after 2020. The U.S. economy is hit hardest in 2019 with a decline in consumption of $2.9 \%$ and a drop in investment of $9.5 \%$. The growth rate may be in negative territory at $-0.1 \%$, and the unemployment rate may rise to $8.4 \%$ in 2019 . The unemployment rate can increase further to a peak of $8.6 \%$ in 2020, although the GDP growth gains $1.9 \%$ in the same year. In the aborted trade war scenario, the worst years of the U.S. economy will be in 2018 and 2019 in terms of consumption, investment and unemployment, although the impacts on the U.S. economy are weaker than in the full trade war scenario. Either a full trade war or an aborted trade war could make the U.S. economy slow substantially for a decade [Noland, Robinson, Moran, 2016] (Fig. 14 and Table 2).

U.S. protectionism would damage exports of Northeast Asian countries. However, tax cuts and infrastructure investment could benefit not only Northeast Asian countries' exports, but also other global exports. At the same time, U.S. protectionist policy could generate uncertainty regarding global trade although China and Japan in particular could play more important roles in global trade and governance. The U.S. withdrawal from the Trans-Pacific Partnership (TPP) generates opportunities for China, Japan and Korea. China can lead free trade by completing the Regional Cooperation and Economic Partnership (RCEP) in the Asia and Pacific Region. 


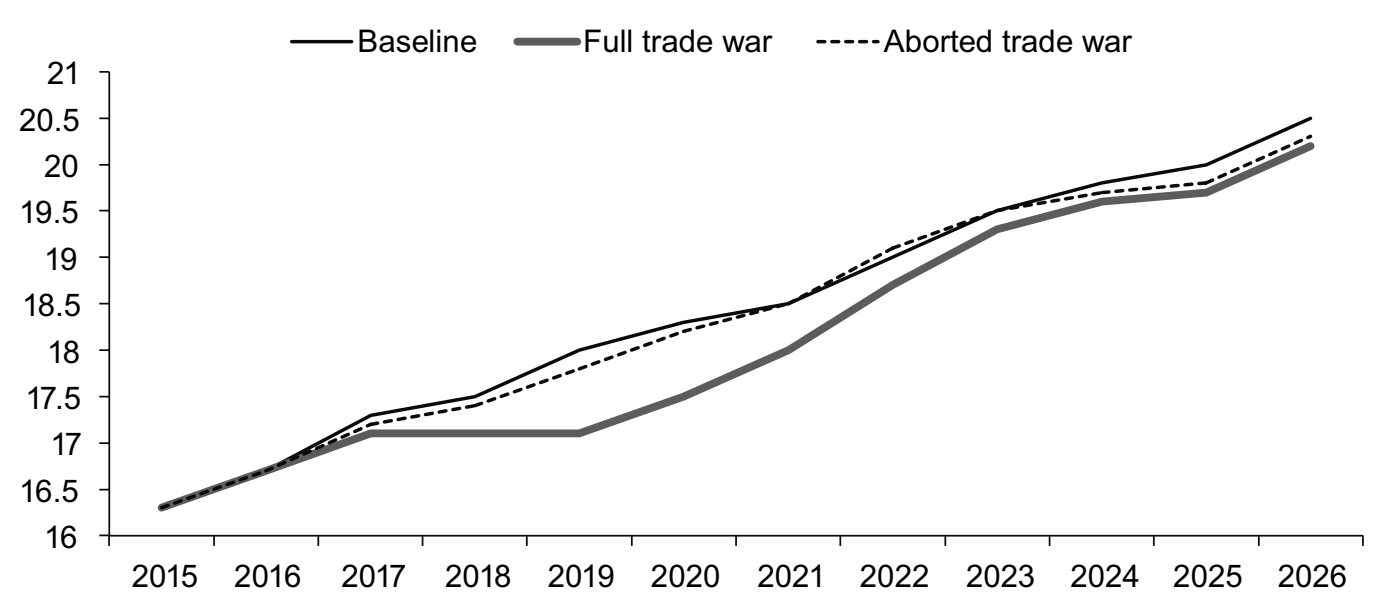

Fig. 14. Projected U.S. GDP under Baseline, Full Trade War and Aborted Trade War Scenarios (2015-2026, \$ Trillions)

Source: [Noland, Robinson, Moran, 2016].

Table 2. Projected Changes in Macroeconomic Variables as a Result of a Full Trade War and an Aborted Trade War (2017-2026, \%)

\begin{tabular}{|c|c|c|c|c|c|}
\hline \multicolumn{7}{|c|}{ Percent Deviation from Baseline } & \multicolumn{2}{c|}{ Projected } \\
\hline \multicolumn{7}{|c|}{ Year } & Consumption & Investment & Government & GDP Growth & Unemployment \\
\hline 2017 & -0.2 & -0.5 & -0.2 & 2.7 & 4.9 \\
\hline 2018 & -1.7 & -5.2 & -1.6 & 0.3 & 6.4 \\
\hline 2019 & -2.9 & -9.5 & -2.7 & -0.1 & 8.4 \\
\hline 2020 & -3.0 & -8.7 & -2.9 & 1.9 & 8.6 \\
\hline 2021 & -2.4 & -5.1 & -2.7 & 3.2 & 7.8 \\
\hline 2022 & -1.6 & -0.8 & -2.1 & 3.7 & 6.6 \\
\hline 2023 & -1.1 & 2.1 & -1.3 & 3.2 & 5.6 \\
\hline 2024 & -1.0 & 2.3 & -0.9 & 2.1 & 5.3 \\
\hline 2025 & -1.2 & 0.8 & -0.8 & 1.4 & 5.5 \\
\hline 2026 & -1.5 & -1.0 & -1.0 & 1.3 & 5.9 \\
\hline \multicolumn{7}{|c|}{ Aborted Trade War } & & \\
\hline 2017 & -0.2 & -0.2 & -0.1 & 2.9 & 4.8 \\
\hline 2018 & -1.3 & -3.4 & 1.2 & 1.2 & 5.6 \\
\hline 2019 & -0.6 & -3.5 & -0.8 & 2.2 & 6.0 \\
\hline 2020 & 0.1 & -0.2 & 0.0 & 2.7 & 5.2 \\
\hline 2021 & 0.0 & 0.3 & -0.3 & 1.9 & 5.3 \\
\hline 2022 & 0.2 & 2.5 & 0.2 & 2.9 & 4.8 \\
\hline 2023 & 0.2 & 1.9 & 0.3 & 2.0 & 4.7 \\
\hline 2024 & 0.0 & 0.0 & 0.2 & 1.4 & 5.1 \\
\hline 2025 & -0.2 & -0.9 & 0.1 & 1.6 & 5.2 \\
\hline 2026 & -0.2 & -0.7 & 0.0 & 2.0 & 5.1 \\
\hline
\end{tabular}

Source: [Noland, Robinson, Moran, 2016]. 
Based on this framework, China possesses a high potential to play a greater role in the global free trade system and global governance. Japan could take over the U.S.'s position in the TPP and lead it although the possibility of completing the TPP is rather low because the U.S. portion accounts for nearly $65 \%$ of the total. Despite this fact, Japan succeeded in completing the CPTPP with the remaining 11 nations in March 2018. Korea can create more benefits by participating in the two mega FTAs if Japan can complete the TPP without U.S. participation, and if Korea responds wisely to U.S. protectionism based on its bilateral FTA with the United States. The renegotiation of the KORUS FTA started in 2017, and both parties are trying to update it based on free, fair and balanced trade to meet their reciprocal national interest in renegotiation rather than abandonment of the bilateral FTA. The prospects are good on this front because the Trump administration prefers bilateral FTAs to the multilateral ones in its trade policy [Liu, Yi, Liang, 2016; Genereux, 2017].

Additionally, it is an urgent issue for Northeast Asian countries to complete the regional trilateral FTA between China, Japan and Korea in order to collectively respond to U.S. protectionism. At the same time, the RCEP can play a significant role in establishing a platform for protecting not only Northeast Asian economic interests, but also the interests of the region as a whole. Accordingly, the RCEP could build a proper and efficient seawall against U.S. protectionism so that Northeast Asian economies can grow further in the future.

\section{Concluding Remarks}

The process of globalization goes back to the late-19th century. Since then, global free trade expanded until World War I and faced strong political backlash due to income inequality and increasing unemployment in the advanced nations. As a result, many advanced nations such as the UK and the U.S. initiated the first wave of protectionism. The first wave of globalization contributed to World War I and the Great Depression which eventually resulted in World War II. In the post-war context, the U.S. with its allies established a new economic order based on supranational institutions such as the World Bank, IMF and GATT in order to rebuild the world economy.

These supranational institutions emphasized global free trade, reducing tariffs, boosting capital investment and supporting technology development. As a result, the world economy started to grow rapidly from the 1950s. In the 1970s and 1990s, even China and India joined the global economic system and the Soviet Union and Eastern European countries also participated in the free trade system after their economic and political crash. The second wave of globalization intensified until the global financial crisis in 2008. After the global financial crisis, protectionist sentiment increased around the world. This time, the source of the second political backlash was not only the advanced nations, but also the developing nations. In order to overcome this economic and political movement, G20 members announced their intention to protect the free trade system in 2010 although many members had implemented protectionist measures in their own trade policies.

Since then, the deglobalization trend has continued particularly in the U.S. and the UKthis seems paradoxical because these nations started and strengthened the globalization process based on the free trade system. After the U.S. presidential election in 2016, the Trump government has argued that the free trade system must be replaced by a fair trade system. However, this fair trade system is mainly based on high tariffs and renegotiation of FTAs such as NAFTA and the KORUS, and on withdrawal from the TPP. This represents the second wave of protectionism. The question is how fully the U.S. government may implement its trade policy given its impacts on the global economy directly and indirectly. Many economists assume that the U.S. 
government cannot set high tariffs on import goods because U.S. consumer and export prices will increase at the same time, even though the U.S. economy is less exposed than small, open economies. Protectionism is a double-edged sword even for the U.S. economy.

U.S. protectionism would strongly impact Northeast Asian countries because China, Japan and Korea are global manufacturing hubs and much more trade dependent than the United States. Additionally, these nations react to U.S. trade policies individually instead of collectively because they have not created any formal regional economic integration. Therefore, they are more vulnerable than other regional economic zones such as the EU.

In fact, U.S. protectionism mainly targets Northeast Asian countries because the U.S. trade deficit was primarily with China, Japan and Korea in 2015 (62\%), while its trade deficit was only $20 \%$ with the EU in the same year. Therefore, Northeast Asian countries must act wisely and properly against U.S. protectionism. This will allow them to protect their own economic interests in particular and the interest of East Asia as a whole.

\section{References}

Acemoglu D. (2009) Modern Economic Growth. Princeton, NJ: Princeton University Press.

Aichelle R., Felbermayr G., Heiland I. (2016) Going Deep: The Trade and Welfare Effects of TTIP Revised. IFO Working Paper, no 219, July.

Alvaredo F., Chancel L., Piketty T., Saez E., Zucman G. (2017) World Inequality Report 2018, Executive Summary. Available at: http://wir2018.wid.world/ (accessed 27 December 2017).

Asia Regional Integration Center (2017) Free Trade Agreements. Available at: https://aric.adb.org/fta-all (accessed 15 May 2017).

Basu Das S. (2017) De-Globalisation Sentiment Carries Risks for ASEAN Economies. Yusof Ishak Institute Perspective, no 15. Available at: https://web5.iseas.edu.sg/images/pdf/ISEAS_Perspective_2017_15.pdf (accessed 20 March 2018).

Bhagwati J. (2009) Does the U.S Need a New Trade Policy? Journal of Policy Modeling, vol. 31, no 4, pp. 509-514.

Bradford S., Greico P., Hufbauer G.C. (2006) The Payoff to America from Globalisation. The World Economy, vol. 29, no 7, pp. 893-917.

Brasher K., Perlez J. (2018) Is Trump Serious About Trade War? China's Leaders Hunt for Answers. New York Times, 12 April.

Broda C., Weinstein D.E. (2006) Globalization and the Gains from Variety. The Quarterly Journal of Economics, vol. 121, no 2, pp. 541-585.

Chicago Council on Global Affairs (2010a) Global Views 2010. Chicago, IL: CCFR.

Chicago Council on Global Affairs (2010b) Global Views 2010: Detailed Findings. Chicago, IL: CCFR.

Dunn B. (2015) Neither Free Trade Nor Protection: A Critical Political Economy of Trade Theory and Practice. Available at: https://www.elgaronline.com/view/9781783471928.00007.xml (accessed 23 November 2017).

Economic Report of the President (2009) Economic Report of the President Together with the Annual Report of the Council of Economic Advisers. Available at: https://fraser.stlouisfed.org/files/docs/publications/ ERP/2009/2009_ERP.pdf (accessed 20 March 2018).

Evenett S., Fritz J. (2017) Awe Trumps Rules: An Update on this Year's G20 Protectionism. 6 July. Available at: https://voxeu.org/article/awe-trumps-rules-update-year-s-g20-protectionism (accessed 20 March 2018).

Feenstra R.C., Mandel B.R., Reinsdorf M.B., Slaughter M. (2009) Effects of Terms of Trade Gains and Tariff Changes on the Measurement of U.S. Productivity Growth. National Bureau of Economic Research Working Paper No 15592. December. Available at http://www.nber.org/papers/w15592.pdf (accessed 20 March 2018).

Feinman J.N. (2016) A Closer Look: Backlash against Globalization: Déjà vu? Deutsch Asset Management. Available at: https://fundsus.deutscheam.com/EN/docs/research/A_Closer_Look_by_Josh_Feinman-2016-12.pdf (accessed 20 March 2018). 
Felbermayr G., Steininger M., Yalcin E. (2017) Economic Implications of a Protectionist US Trade Policy. 22 November. Available at: http://voxeu.org/article/economic-implications-protectionist-us-trade-policy (accessed 30 November 2017).

Financial Times (2018) Trans Pacific Partnership: Pacific Countries Seek New Members for Trade Deal. 8 March.

Garbade K.D., Silber W.L. (1978) Technology, Communication and the Performance of Financial Markets. The Journal of Finance, vol. 33, no 3, pp. 819-832.

Genereux F. (2017) Protectionism: A Brake on Economic Growth. Economic Studies. 17 February. Available at: https://www.desjardins.com/ressources/pdf/pv170217-e.pdf (accessed 20 March 2018).

Global Trade Alert (2016) Global Trade Alert Report 2016. Available at: http://www.globaltradealert.org/ (accessed 20 March 2018).

Global Trade Alert (2017) Global Trade Alert Report 2017. Available at: http://www.globaltradealert.org/ (accessed 20 March 2018).

Gomory R., Baumol W. (2009) Globalization: Country and Company Interests in Conflict. Journal of Policy Modeling, vol. 31, no 3, pp. 540-555.

Graceffo A. (2017) China at Davos: US-China Relations Are the Focus of the World Economic Forum. 23 January. Foreign Policy Journal. Available at: https://www.foreignpolicyjournal.com/2017/01/24/china-atdavos-us-china-relations-are-the-focus-of-the-world-economic-forum/ (accessed 15 April 2017).

Hendrix C.S. (2016) Protectionism in the 2016 Election: Causes and Consequences, Truth and Frictions. Policy Brief PB 16-20. Peterson Institute for International Economics. Available at: https://piie.com/system/files/ documents/pb16-20.pdf (accessed 20 March 2018).

Hofschire D., Emsbo-Mattingly L., Dourney C., Wilde J. (2017) For Now, the Risks of Trade Protectionism are Offset by Global Reacceleration. Fidelity Investment Leadership Series. February. Available at: https:// www.fidelity.com/webcontent/ap101883-markets_sectors-content/17.02/business_cycle/history/BCU_February_2017.pdf (accessed 20 March 2018).

Hufbauer G., Jung E. (2016) Evaluating Trump's Trade Policies. 29 September. Available at: http://voxeu.org/ article/evaluating-trump-s-trade-policies (accessed 1 December 2017).

Hearn A.H., Myers M. (2015) China and TPP: Asia Pacific Integration or Disintegration? The Dialogue: China and Latin America Report, July. Available at: https://www.thedialogue.org/wp-content/uploads/2015/07/ CLA-TPP-Report-final-web.pdf (accessed 20 March 2018).

Higham J. (1955) Strangers in the Land: Patterns of American Nativism, 1860-1925. Rutgers: Rutgers University Press.

Hillebrand E.E., Lewer J.J., Zagardo J.T. (2010) Backtracking from Globalization. Global Economy Journal, vol. 10 , no 4, pp. 1-17.

International Monetary Fund (IMF) (2017) World Economic Outlook Update: A Shifting Global Economic Landscape. January. Available at: http://www.imf.org/external/pubs/ft/weo/2017/update/01/ (accessed 20 March 201).

Krugman P.R. (1979) Increasing Returns, Monopolistic Competition and International Trade. Journal of International Economics, vol. 9, no 4, pp. 469-479.

Krugman P.R. (2008) Trade and Wages, Reconsidered, Proceedings. Available at: http://www.princeton. edu/ pkrugman/pk-bpea-draft.pdf (accessed 16 April 2018).

Krugman P.R., Obstfeld M. (2009) International Economics, Boston, MA: Pearson, Addison-Wesley.

Lawrence R.Z., Weinstein D.E. (1999) Trade and Growth: Import-Led or Export-Led? Evidence from Japan and Korea, National Bureau of Economic Research Working Paper no 7264. Available at: http://www.nber. org/papers/w7264.pdf (accessed 20 March 2018).

Lewer J.J., Van den Berg H. (2007) International Trade and Economic Growth. Armonk, NY: M.E. Sharpe.

Liu L., Yi E., Liang H. (2016) What Does Donald Trump's Protectionist Policy Mean for China? China Macro Thematic Report. Beijing: CICC.

Maddison A. (2001) The World Economy: A Millennial Perspective. Paris: OECD Development Centre Studies. 
Mathieson R. (2017) Agreeing on China's Favorite Trade Deal Set to Drag into 2018. 14 November. Available at: https://www.bloomberg.com/news/articles/2017-11-13/agreeing-on-china-s-favorite-trade-deal-set-todrag-into-2018 (accessed 22 November 2017).

Noland M., Robinson S., Moran T. (2016) Impact of Clinton's and Trump's Trade Proposals (M. Noland, G.C. Hufbauer, S. Robinson, Moran T. (eds.)). Assessing Trade Agendas in the US Presidential Campaign, Peterson Institute for International Economics (PIIE) Briefing 16-6, pp. 17-39. Available at: https://www. rexsresources.com/uploads/6/5/2/1/6521405/piieb16-6.pdf (accessed 16 April 2018).

Nhan Dan (2017) RCEP Trade Deal Expected to Be Signed in 2018. 13 November. Available at: http://en.nhandan. com.vn/world/item/5640902-rcep-trade-deal-expected-to-be-signed-in-2018.htm (accessed 22 November 2017).

Ocampo J. (2004) Latin America's Growth and Equity Frustrations during Structural Reform. Journal of Economic Perspectives, vol. 18, no 2, pp. 67-88.

Organisation for Economic Co operation and Development (OECD) (2014) Factbook 2014. Available at: http://www.oecd-ilibrary.org/economics/oecd-factbook-2014_factbook-2014-en (accessed 20 March 2018).

O'Rourke K.H., Williamson J.G. (2001) Globalization and History: The Evolution of Nineteenth Century Atlantic Economy. Cambridge, MA: The MIT Press.

Park S.C. (2016) Korea's Trade Strategies for Mega Free Trade Agreements in Regional and Global Economic Integration. International Organisations Research Journal, vol. 11, no 4, pp. 177-204 (in Russian and English). DOI: 10.17323/1996-7845-2016-04-177.

Piketty T. (2014) Capital in the Twenty First Century. Cambridge, MA: Belknap Press.

Rosen H. (2008) Strengthening Trade Adjustment Assistance. Peterson Institute for International Economics Policy Brief PD 09-2. January. Available at: https://piie.com/publications/pb/pb08-2.pdf (accessed 20 March 2018).

Samuelson P. (2004) Where Ricardo and Mill Rebut and Confirm Arguments of Mainstream Economists Supporting Globalization. Journal of Economic Perspectives, vol. 18, no 3, pp. 135-146.

UN Comtrade (2016) UN Comtrade Database. Available at: https://comtrade.un.org/ (accessed 16 April 2018).

United States Census (2017) Foreign Trade. Available at: https://www.census.gov/foreign-trade/balance/ c5800.html (accessed 4 June 2017).

United States Trade Representative (USTR) (2017a) USTR Releases NAFTA Negotiating Objectives. July. Available at: https://ustr.gov/about-us/policy-offices/press-office/press-releases/2017/july/ustr-releases-nafta-negotiating (accessed 23 November 2017).

United States Trade Representative (USTR) (2017b) USTR Calls a Special Session Under the U.S. Korea Free Trade Agreement. July. Available at: https://ustr.gov/about-us/policy-offices/press-office/press-releases/2017/july/ustr-calls-special-session-under-us (accessed 23 November 2017).

World Bank (2017) World Bank Data Base. Available at: http://data.worldbank.org/indicator/BX.KLT.DINV. WD.GD.ZS (accessed 2 June 2017).

World Trade Organization (WTO) (2015) International Trade Statistics 2015. Available at: https://www.wto. org/english/res_e/statis_e/its2015_e/its2015_e.pdf (accessed 1 June 2017).

World Trade Organization (WTO) (2016) World Trade Statistical Review. Available at: https://www.wto.org/ english/res_e/statis_e/wts2016_e/wts2016_e.pdf (accessed 31 May 2017).

World Trade Organization (WTO) (2017a) Trade Statistics and Outlook: Trade Recovery Expected in 2017 and 2018, Amid Policy Uncertainty. Press Release 791. 12 April. Available at: https://www.wto.org/english/news_e/ pres17_e/pr791_e.htm (accessed 20 March 2018).

World Trade Organization (WTO) (2017b) World Trade Statistical Review 2017. Available at: https://www.wto. org/english/res_e/statis_e/wts2017_e/wts2017_e.pdf (accessed 16 April 2018). 


\title{
Протекционизм США и нарушение торгового баланса между США и странами Северо-Восточной Азии ${ }^{1}$
}

\author{
С. - - Пак
}

Пак Санг-Чул - профессор Высшей школы наукоемких технологий и энергетики Политехнического университета Республики Корея; 2121 Jeongwang-Dong, Siheung-City, Kyonggi-Do, 429-793, Korea; E-mail: scpark@kpu.ac.kr

После глобального финансового кризиса рост мировой торговли замедлился. В 2016 г. объем мировой торговли увеличился на 1,9\%, что ниже показателя 2015 г. - 2,8\%. Согласно прогнозам, в 2017 г. импорт развитых стран будет умеренным, в то время как спрос на импортируемые товары в развивающихся азиатских экономиках может продолжать расти. Несмотря на растущий импорт в Азии, начиная с 2013 г. темп роста мировой торговли был ниже темпа глобального экономического роста. В этих условиях многие страны стремились к заключению двусторонних, многосторонних, региональных и мегасоглашений о свободной торговле (ССТ), чтобы повысить объемы собственной торговли и стимулировать экономический рост. Восточноазиатские страны стремятся построить свою систему региональных ССТ и принимать участие в различных мегаССТ, таких как Всеобъемлющее региональное экономическое партнерство (ВРЭП) и Транстихоокеанское партнерство (ТТП). Все это привело к еще большему расхождению экономических интересов, в том числе в силу несовпадения взглядов в сфере политики и безопасности в Восточноазиатском регионе. Так, политика протекционизма, начатая администрацией президента США Дональда Трампа, стала угрозой для ТТП, хотя премьер-министр Японии Синдзо Абэ стремится к тому, чтобы соглашение продолжило действовать, несмотря на выход США. В данной статье предпринята попытка исследовать политику протекционизма США под руководством президента Дональда Трампа, ответить на вопрос, почему страна перешла от свободной и открытой торговли к так называемой справедливой торговле, основанной на принципе «Америка прежде всего». Также в статье рассматриваются торговые дисбалансы между США и странами Северо-Восточной Азии, прежде всего их причины. Наконец, что не менее важно, автор рассуждает о том, как политика протекционизма США повлияет на мегаССТ, такие как ВРЭП и ТТП, а также экономическое сотрудничество восточноазиатских стран.

Работа выполнена при поддержке Национального исследовательского фонда Правительства Республики Корея (NRF2015S1A3A2046684).

Ключевые слова: протекционизм; мегаССТ; экономический рост; нарушение торгового баланса; свободная торговля; «справедливая» торговля

Для цитирования: Пак С.-Ч. (2018) Протекционизм США и нарушение торгового баланса между США и странами Северо-Восточной Азии // Вестник международных организаций. 2018. Т. 13. № 2. С. 76-100 (на русском и английском языках). DOI: 10.17323/1996-7845-2018-02-05.

\section{Источники}

Acemoglu D. (2009) Modern Economic Growth. Princeton, NJ: Princeton University Press.

Aichelle R., Felbermayr G., Heiland I. (2016) Going Deep: The Trade and Welfare Effects of TTIP Revised. IFO Working Paper. No. 19 (July).

Alvaredo F., Chancel L., Piketty T., Saez E., Zucman G. (2017) World Inequality Report 2018, Executive Summary. Режим доступа: http://wir2018.wid.world/ (дата обращения: 27.12.2017).

Asia Regional Integration Center (2017) Free Trade Agreements. Режим доступа: https://aric.adb.org/fta-all (дата обращения: 15.05.2017).

\footnotetext{
${ }^{1}$ Статья поступила в редакцию в ноябре 2017 г.
} 
Basu Das S. (2017) De-Globalisation Sentiment Carries Risks for ASEAN Economies / YusofIshak Institute Perspective. No. 15. Режим доступа: https://web5.iseas.edu.sg/images/pdf/ISEAS_Perspective_2017_15.pdf (дата обращения: 20.03.2018).

Bhagwati J. (2009) Does the U.S Need a New Trade Policy? // Journal of Policy Modeling. Vol. 31. No. 4. P. 509-514.

Bradford S., Greico P., Hufbauer G.C. (2006) The Payoff to America from Globalisation // The World Economy. Vol. 29. No. 7. P. 893-917.

Brasher K., Perlez J. (2018) Is Trump Serious About Trade War? China's Leaders Hunt for Answers // New York Times. 12 April.

Broda C., Weinstein D.E. (2006) Globalization and the Gains from Variety//The Quarterly Journal of Economics. Vol. 121. No. 2. P. 541-585.

Chicago Council on Global Affairs (2010a) Global Views 2010. Chicago, IL: CCFR.

Chicago Council on Global Affairs (2010b) Global Views 2010: Detailed Findings. Chicago, IL: CCFR.

Dunn B. (2015) Neither Free Trade Nor Protection: A Critical Political Economy of Trade Theory and Practice. Режим доступа: https://www.elgaronline.com/view/9781783471928.00007.xml (дата обращения: 23.11.2017).

Economic Report of the President (2009) Economic Report of the President Together with the Annual Report of the Council of Economic Advisers. Режим доступа: https://fraser.stlouisfed.org/files/docs/publications/ ERP/2009/2009_ERP.pdf (дата обрашения: 20.03.2018).

Evenett S., Fritz J. (2017) Awe Trumps Rules: An Update on this Year's G20 Protectionism. 6 July. Режим доступа: https://voxeu.org/article/awe-trumps-rules-update-year-s-g20-protectionism (дата обращения: 20.03.2018).

Feenstra R.C., Mandel B.R., Reinsdorf M.B., Slaughter M. (2009) Effects of Terms of Trade Gains and Tariff Changes on the Measurement of U.S. Productivity Growth. National Bureau of Economic Research Working Paper No. 15592. December. Режим доступа: http://www.nber.org/papers/w15592.pdf (дата обращения: 20.03.2018).

Feinman J.N. (2016) A Closer Look: Backlash against Globalization: Déjà vu? Deutsch Asset Management. Режим доступа: https://fundsus.deutscheam.com/EN/docs/research/A_Closer_Look_by_Josh_Feinman2016-12.pdf (дата обращения: 20.03.2018).

Felbermayr G., Steininger M., Yalcin E. (2017) Economic Implications of a Protectionist US Trade Policy. 22 November. Режим доступа: http://voxeu.org/article/economic-implications-protectionist-us-trade-poliсу (дата обращения: 30.11.2017).

Financial Times (2018) Trans Pacific Partnership: Pacific Countries Seek New Members for Trade Deal. 8 March.

Garbade K.D., Silber W.L. (1978) Technology, Communication and the Performance of Financial Markets // The Journal of Finance. Vol. 33. No. 3. P. 819-832.

Genereux F. (2017) Protectionism: A Brake on Economic Growth // Economic Studies. 17 February. Режим доступа: https://www.desjardins.com/ressources/pdf/pv170217-e.pdf (дата обращения: 20.03.2018).

Global Trade Alert (2016) Global Trade Alert Report 2016. Режим доступа: http://www.globaltradealert.org/ (дата обрашения: 20.03.2018).

Global Trade Alert (2017) Global Trade Alert Report 2017. Режим доступа: http://www.globaltradealert.org/ (дата обращения: 20.03.2018).

Gomory R., Baumol W. (2009) Globalization: Country and Company Interests in Conflict // Journal of Policy Modeling. Vol. 31. No. 3. P. 540-555.

Graceffo A. (2017) China at Davos: US-China Relations Are the Focus of the World Economic Forum. 23 January // Foreign Policy Journal. Режим доступа: https://www.foreignpolicyjournal.com/2017/01/24/ china-at-davos-us-china-relations-are-the-focus-of-the-world-economic-forum/ (дата обращения: 15.04. 2017). 
Hendrix C.S. (2016) Protectionism in the 2016 Election: Causes and Consequences, Truth and Frictions. Policy Brief PB 16-20. Peterson Institute for International Economics. Режим доступа: https://piie.com/system/ files/documents/pb16-20.pdf (дата обращения: 20.03.2018).

Hofschire D., Emsbo-Mattingly L., Dourney C., Wilde J. (2017) For Now, the Risks of Trade Protectionism are Offset by Global Reacceleration. Fidelity Investment Leadership Series. February. Режим доступа: https://www.fidelity.com/webcontent/ap101883-markets_sectors-content/17.02/business_cycle/history/ BCU_February_2017.pdf (дата обращения: 20.03.2018).

Hufbauer G., Jung E. (2016) Evaluating Trump's Trade Policies. 29 September. Режим доступа: http://voxeu. org/article/evaluating-trump-s-trade-policies (дата обращения: 01.12.2017).

Hearn A.H., Myers M. (2015) China and TPP: Asia Pacific Integration or Disintegration? The Dialogue: China and Latin America Report, July. Режим доступа: https://www.thedialogue.org/wp-content/uploads/2015/07/ CLA-TPP-Report-final-web.pdf (дата обращения: 20.03.2018).

Higham J. (1955) Strangers in the Land: Patterns of American Nativism, 1860-1925. Rutgers: Rutgers University Press.

Hillebrand E.E., Lewer J.J., Zagardo J.T. (2010) Backtracking from Globalization // Global Economy Journal. Vol. 10. No. 4. P. 1-17.

International Monetary Fund (IMF) (2017) World Economic Outlook Update: A Shifting Global Economic Landscape. January. Режим доступа: http://www.imf.org/external/pubs/ft/weo/2017/update/01/ (дата обращения: 20.03.2018).

Krugman P.R. (1979) Increasing Returns, Monopolistic Competition and International Trade // Journal of International Economics. Vol. 9. No. 4. P. 469-479.

Krugman P.R. (2008) Trade and Wages, Reconsidered, Proceedings. Режим доступа: http://www.princeton. edu/ pkrugman/pk-bpea-draft.pdf (дата обращения: 16.04.2018).

Krugman P.R., Obstfeld M. (2009) International Economics, Boston, MA: Pearson, Addison-Wesley.

Lawrence R.Z., Weinstein D.E. (1999) Trade and Growth: Import-Led or Export-Led? Evidence from Japan and Korea, National Bureau of Economic Research Working Paper No 7264. Режим доступа: http://www. nber.org/papers/w7264.pdf (дата обращения: 20.03.2018).

Lewer J.J., Van den Berg H. (2007) International Trade and Economic Growth. Armonk, NY: M.E. Sharpe.

Liu L., Yi E., Liang H. (2016) What Does Donald Trump's Protectionist Policy Mean for China? China Macro Thematic Report. Beijing: CICC.

Maddison A. (2001) The World Economy: A Millennial Perspective. Paris: OECD Development Centre Studies.

Mathieson R. (2017) Agreeing on China's Favorite Trade Deal Set to Drag into 2018. 14 November. Режим доступа: https://www.bloomberg.com/news/articles/2017-11-13/agreeing-on-china-s-favorite-trade-deal-set-todrag-into-2018 (дата обращения: 22.11.2017).

Noland M., Robinson S., Moran T. (2016) Impact of Clinton's and Trump's Trade Proposals / M. Noland, G.C. Hufbauer, S. Robinson, T. Moran (eds). Assessing Trade Agendas in the US Presidential Campaign, Peterson Institute for International Economics (PIIE) Briefing 16-6. P. 17-39. Режим доступа: https://www. rexsresources.com/uploads/6/5/2/1/6521405/piieb16-6.pdf (дата обращения: 16.04.2018).

Nhan Dan (2017) RCEP Trade Deal Expected to Be Signed in 2018. 13 November. Режим доступа: http:// en.nhandan.com.vn/world/item/5640902-rcep-trade-deal-expected-to-be-signed-in-2018.htm (дата обращения: 22.11.2017).

Ocampo J. (2004) Latin America's Growth and Equity Frustrations during Structural Reform // Journal of Economic Perspectives. Vol. 18. No. 2. P. 67-88.

Organisation for Economic Co operation and Development (OECD) (2014) Factbook 2014. Режим доступа: http://www.oecd-ilibrary.org/economics/oecd-factbook-2014_factbook-2014-en (дата обращения: 20.03.2018).

O'Rourke K.H., Williamson J.G. (2001) Globalization and History: The Evolution of Nineteenth Century Atlantic Economy. Cambridge, MA: The MIT Press. 
Park S.C. (2016) Korea's Trade Strategies for Mega Free Trade Agreements in Regional and Global Economic Integration // International Organizations Research Journal. Vol. 11. No. 4. P. 177-204. (In Russian and English.) DOI: 10.17323/1996-7845-2016-04-177.

Piketty T. (2014) Capital in the Twenty First Century. Cambridge, MA: Belknap Press.

Rosen H. (2008) Strengthening Trade Adjustment Assistance. Peterson Institute for International Economics Policy Brief PD 09-2. January. Режим доступа: https://piie.com/publications/pb/pb08-2.pdf (дата обращения: 20.03.2018).

Samuelson P. (2004) Where Ricardo and Mill Rebut and Confirm Arguments of Mainstream Economists Supporting Globalization // Journal of Economic Perspectives. Vol. 18. No. 3. P. 135-146.

UN Comtrade (2016) UN Comtrade Database. Режим доступа: https://comtrade.un.org/ (дата обращения: 16.04.2018).

United States Census (2017) Foreign Trade. Режим доступа: https://www.census.gov/foreign-trade/balance/ c5800.html (дата обращения: 04.06.2017).

United States Trade Representative (USTR) (2017a) USTR Releases NAFTA Negotiating Objectives. July. Peжим доступа: https://ustr.gov/about-us/policy-offices/press-office/press-releases/2017/july/ustr-releasesnafta-negotiating (дата обращения: 23.11.2017).

United States Trade Representative (USTR) (2017b) USTR Calls a Special Session Under the U.S. Korea Free Trade Agreement. July. Режим доступа: https://ustr.gov/about-us/policy-offices/press-office/press-releases/2017/july/ustr-calls-special-session-under-us (дата обращения: 23.11.2017).

World Bank (2017) World Bank Data Base. Режим доступа: http://data.worldbank.org/indicator/BX.KLT. DINV.WD.GD.ZS (дата обращения: 02.06.2017).

World Trade Organization (WTO) (2015) International Trade Statistics 2015. Режим доступа: https://www. wto.org/english/res_e/statis_e/its2015_e/its2015_e.pdf (дата обращения: 01.06.2017).

World Trade Organization (WTO) (2016) World Trade Statistical Review. Режим доступа: https://www.wto. org/english/res_e/statis_e/wts2016_e/wts2016_e.pdf (дата обращения: 31.05.2017).

World Trade Organization (WTO) (2017a) Trade Statistics and Outlook: Trade Recovery Expected in 2017 and 2018, Amid Policy Uncertainty. Press Release 791. 12 April. Режим доступа: https://www.wto.org/english/ news_e/pres17_e/pr791_e.htm (дата обращения: 20.03.2018).

World Trade Organization (WTO) (2017b) World Trade Statistical Review 2017. Режим доступа: https://www. wto.org/english/res_e/statis_e/wts2017_e/wts2017_e.pdf (дата обращения: 16.04.2018). 